\title{
Zróżnicowanie zagranicznej turystyki przyjazdowej w Unii Europejskiej w czasach kryzysu gospodarczego
}

\author{
Diversification of International Tourism \\ in European Union under Economic Crisis
}

\begin{abstract}
Streszczenie: W okresie kryzysu ekonomicznego nastąpił spadek tempa wzrostu przyjazdów turystów zagranicznych, zarówno na świecie (np. w okresie 2008-2009 liczba przyjazdów turystów zagranicznych spadła z 919 do $880 \mathrm{mln}$ ), jak i w Unii Europejskiej (spadek z 486 do $462 \mathrm{mln}$ ). Celem niniejszego artykułu jest ukazanie wpływu światowego kryzysu ekonomicznego na natężenie i przestrzenne zróżnicowanie międzynarodowego ruchu turystycznego do krajów Unii Europejskiej na początku XXI wieku, ze szczególnym uwzględnieniem lat 2007-2011. Przeanalizowano przyjazdy turystów zagranicznych do Unii Europejskiej i jej wybranych krajów, generujących największy ruch przyjazdowy, oraz omówiono zmiany w strukturze tych przyjazdów. Przedstawiono także zróżnicowanie wpływów z turystyki międzynarodowej wybranych krajów UE w badanym okresie. Na ruch turystyczny wpływają także przemiany demograficzne, zwłaszcza proces starzenia się ludności. W związku z tym przebadano również zróżnicowanie ruchu turystycznego i wydatków na turystykę zagraniczną według wieku.
\end{abstract}

\begin{abstract}
During the economic crisis, there has been a decline in the rate of growth of foreign tourist arrivals, both in the world (for example, in 2008-2009 the number of foreign tourist arrivals fell from 919 to 880 million) and the European Union (down from 486 to 462 million). The purpose of this article is to show an impact of world economic crisis on the intensity and spatial variation of international tourism to the countries of the European Union at the beginning of the twenty-first century, with a particular focus on the years 2007-2011. The arrivals of foreign tourists to the European Union and its selected countries were shown generatings the most intensive tourism flows, as well as the changes in the structure of these arrivals were discussed. The diversity of international tourism receipts from selected EU countries during the given period of time was also investigated. Tourism flows are also affected by demographic changes, especially the aging of the population. Therefore the diversity of tourism flows and foreign tourism spending by age was examined.
\end{abstract}

Słowa kluczowe: ruch turystyczny; turystyka międzynarodowa; Unia Europejska; wydatki turystów

Key words: European Union; international tourism; tourism flows; tourist expenses 


\section{WPROWADZENIE}

Turystyka jest jednym z najdynamiczniej rozwijających się sektorów gospodarki oraz jedną z form aktywności ludzkiej, która odgrywa coraz większą rolę w modelu konsumpcji współczesnego człowieka. Według danych UNWTO, liczba turystycznych przyjazdów zagranicznych od 1950 roku, kiedy odnotowano ich 25 milionów, wzrosła ponad 33-krotnie (Mika, Faracik 2008). Przodujące miejsce na świecie pod względem wielkości międzynarodowego ruchu turystycznego zajmuje Unia Europejska, na terenie której w 2011 roku zanotowano 385 milionów podróży turystycznych, co stanowi prawie $40 \%$ ogółu światowego ruchu turystycznego. Związane jest to z dużą atrakcyjnością turystyczną państw członkowskich UE, mającą swoje źródło w bogatym dorobku cywilizacyjno-kulturowym, zróżnicowanym środowisku przyrodniczym, a także w wysokim poziomie usług turystycznych (Kruczek, 2008).

Według Światowej Rady Podróży i Turystyki (World Travel \& Tourism Council, WTTC) gospodarka turystyczna stanowi ponad 9\% udziału w globalnym produkcie brutto na świecie i ma ponad 7,5\% udziału w zatrudnieniu. Te dwa wskaźniki ukazują jej realną ekonomiczną i społeczną pozycję we współczesnym świecie. Powodują tym samym sprzężenie zwrotne pomiędzy rozwojem turystyki a pozostałymi działami gospodarki w różnych układach regionalnych (Dziedzic, Łopaciński, Saja, Szegidewicz, 2009).

Światowy kryzys gospodarczy, który w pełni uwidocznił się w drugiej połowie 2008 roku, wpłynął na większość branż i gospodarek narodowych, w tym również na turystykę (Zdon-Korzeniowska, Rachwał, 2011). Rozpoczął się on od zapaści na rynku pożyczek hipotecznych wysokiego ryzyka w Stanach Zjednoczonych. Główną przyczyną tego stanu rzeczy stała się ryzykowna polityka kredytowa banków, która oparta była na chęci uzyskania maksymalnych zysków (Nosek, Pietrzak, 2009). Doprowadziło to do bankructwa wielu banków. W konsekwencji nastąpiło rozprzestrzenianie się kryzysu gospodarczego, który dotarł również do krajów Unii Europejskiej. Pomiędzy 2008 a 2009 rokiem wartość PKB we wszystkich krajach UE z wyjątkiem Polski uległa zmniejszeniu (według danych Banku Światowego), a największy spadek zanotowały Łotwa (o 18\%), Litwa (o 15\%) oraz Estonia (o 14\%). W sektorze turystyki odczuwalny stał się nacisk światowej recesji gospodarczej, mającej wpływ na wielkość inwestycji turystycznych, rentowność przedsiębiorstw turystycznych i wielkość ruchu turystycznego (Gotowt-Jeziorska, 2011).

Artykuł ma na celu przedstawienie przestrzennego zróżnicowania międzynarodowego ruchu turystycznego do krajów Unii Europejskiej na początku XXI wieku, ze szczególnym uwzględnieniem lat 2008-2011, gdy w większości krajów UE mieliśmy do czynienia z kryzysem ekonomicznym. Przeanalizowano przyjazdy turystów zagranicznych do Unii Europejskiej i jej wybranych państw, generujących największy ruch przyjazdowy, oraz omówiono zmiany w strukturze tych przyjazdów. Przedstawiono również zróżnicowanie wpływów z turystyki międzynarodowej w UE. Ponadto ukazano zróżnicowanie ruchu turystycznego i wydatków na turystykę zagraniczną według wieku. 
W artykule wykorzystano dane statystyczne Światowej Organizacji Turystyki Narodów Zjednoczonych (United Nations World Tourism Organization, UNWTO), Europejskiego Urzędu Statystycznego (European Statistical Office, Eurostat) oraz narodowych instytucji statystycznych państw członkowskich UE.

\section{PrZYJAZDY TURYSTÓW ZAGRANICZNYCH DO PAŃSTW UNII EUROPEJSKIEJ}

W okresie ostatnich 10 lat (od 2001 do 2011 roku) ogólna liczba uczestników międzynarodowej turystyki wzrosła o 43\% (ryc. 1). Przez większość lat ruch turystyczny odnotowywał przyrosty. Wyjątkiem był rok 2003 i 2009, kiedy to wielkość międzynarodowego ruchu turystycznego spadła (w 2003 r. o 1,7\%, a w 2009 r. o 4,2\%). Spadki te spowodowane były epidemią SARS (2003 r.) oraz globalnym kryzysem ekonomicznym (2009 r.) (Pawlicz, 2011).

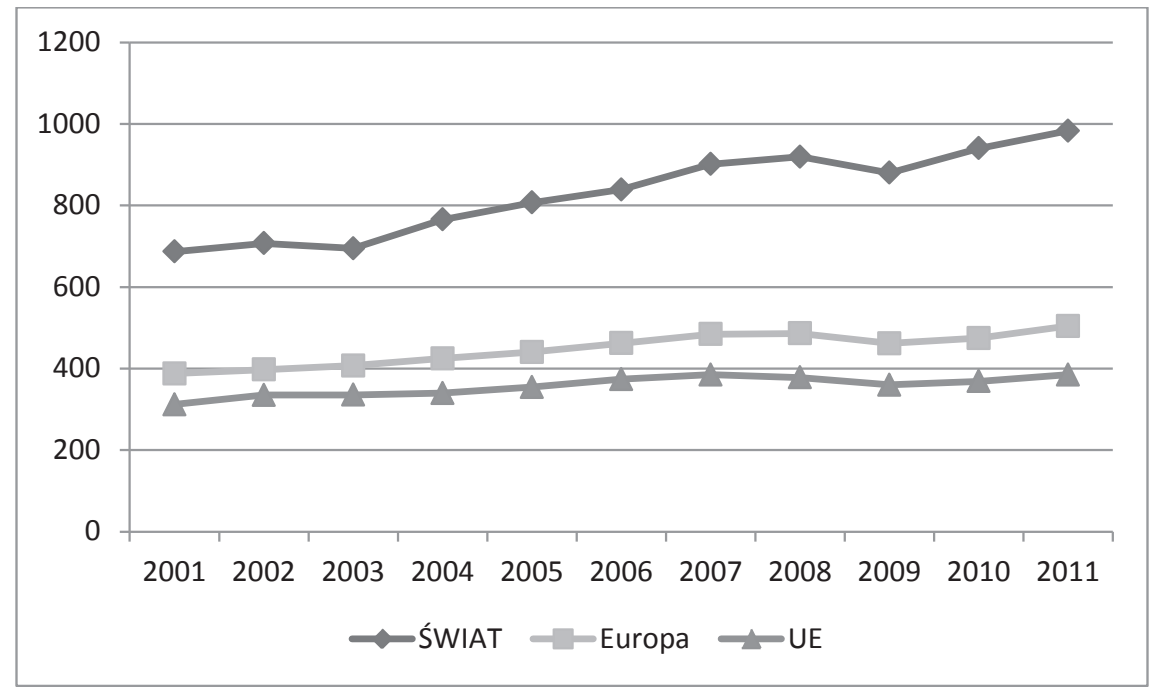

Ryc. 1. Zmiany w liczbie turystów zagranicznych w Europie i Unii Europejskiej na tle świata w latach 2001-2011 (w milionach)

Źródło: opracowanie własne na podstawie danych UNWTO, World Tourism Barometer 2002-2012, Czech Statistical Office, Danmarks Statistik, Statistics Estonia, Ireland Central Statistics Office, Hellenic statistical authority, Statistics Lithuania, Hungarian Central Statistical Office, Portugal Instituto Nacional de Estatistica, Romania Institutul National de Statistica, Statistics Sweden

Turystyka zagraniczna w Unii Europejskiej stanowi jedną czwartą wszystkich przyjazdów turystycznych. Największy udział przyjazdów zagranicznych w 2011 roku zanotowano w Luksemburgu (niemal 100\% przyjazdów ogółem), Belgii (74\%), Słowenii (56\%), Holandii (52\%) oraz Austrii (50\%; EUROSTAT, 2012a, 20012b). W latach 2001-2011 w Europie, a także w Unii Europejskiej spadek przyjazdów turystów międzynarodowych wystąpił jedynie w 2009 roku (w Europie o 4,9\%, a w UE o 4,8\%). Rok później powróciła tendencja 
wzrostowa. W Europie odnotowano wówczas wzrost przyjazdów turystycznych o 2,8\%, a w UE o 2,5\%. W 2011 roku Światowa Organizacja Turystyki Narodów Zjednoczonych szacowała liczbę turystów na 983 miliony osób, z których 51\% podróżowało po Europie, a $39 \%$ po krajach UE.

W latach 2001-2011 rozmieszczenie ruchu turystycznego na terenie Unii Europejskiej nie uległo większym zmianom. Najczęściej odwiedzanym regionem turystycznym Unii Europejskiej (według klasyfikacji Światowej Organizacji Turystyki; UNWTO, 2012) - była Europa Zachodnia, która gościła co roku ponad 37\% turystów podróżujących po UE (według granic z 2012 roku - 27 państw). Niewiele mniejszy udział w międzynarodowym ruchu turystycznym miała Europa Południowo-Śródziemnomorska. Znacznie mniej turystów przyjeżdżało do Europy Środkowo-Wschodniej oraz Europy Północnej (ryc. 2).

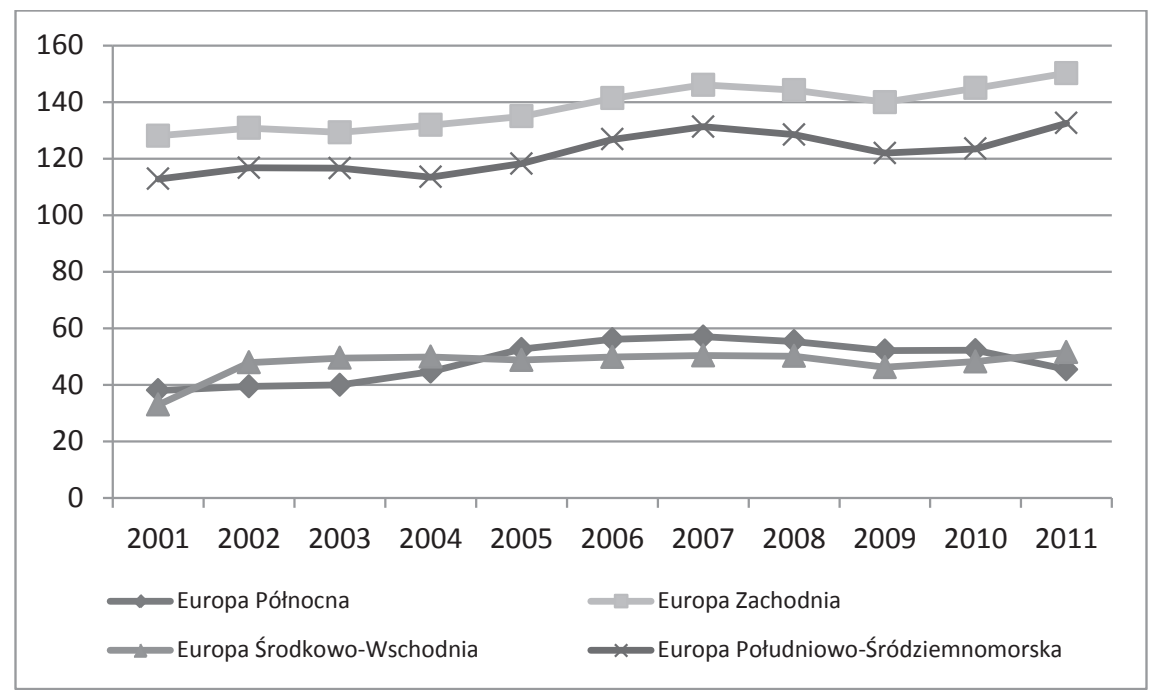

Ryc. 2. Przyjazdy turystów zagranicznych do regionów turystycznych Europy* (w milionach)

Źródło: opracowanie własne na podstawie danych UNWTO, World Tourism Barometer 2002-2012, Czech Statistical Office, Danmarks Statistik, Statistics Estonia, Ireland Central Statistics Office, Hellenic Statistical Authority, Statistics Lithuania, Hungarian Central Statistical Office, Portugal Instituto Nacional de Estatistica, Romania Institutul National de Statistica, Statistics Sweden

* Wzięto pod uwagę tylko kraje należące do Unii Europejskiej.

Wśród państw Unii Europejskiej dominującą rolę w recepcji ruchu turystycznego pełni Francja, która od kilku lat prowadzi w światowych rankingach państw najczęściej odwiedzanych przez turystów. W 2011 roku do Francji przyjechało 79,5 miliona turystów zagranicznych. Istotne miejsce na mapie turystycznej Unii Europejskiej zajmują także Hiszpania i Włochy, które razem z Francją przyjmują prawie połowę (47\%) międzynarodowego ruchu turystycznego w Unii Europejskiej (ryc. 3). Do najchętniej odwiedzanych przez turystów zagranicznych regionów w UE należą: Wyspy Kanaryjskie i Baleary (Hiszpania), 
Inner London (Wielka Brytania), Katalonia (Hiszpania), Île de France (Francja), Wenecja (Włochy) oraz Tyrol w Austrii (według liczby udzielonych noclegów w regionach NUTS 2 w 2010 r.; Eurostat Regional Yearbook, 2012).

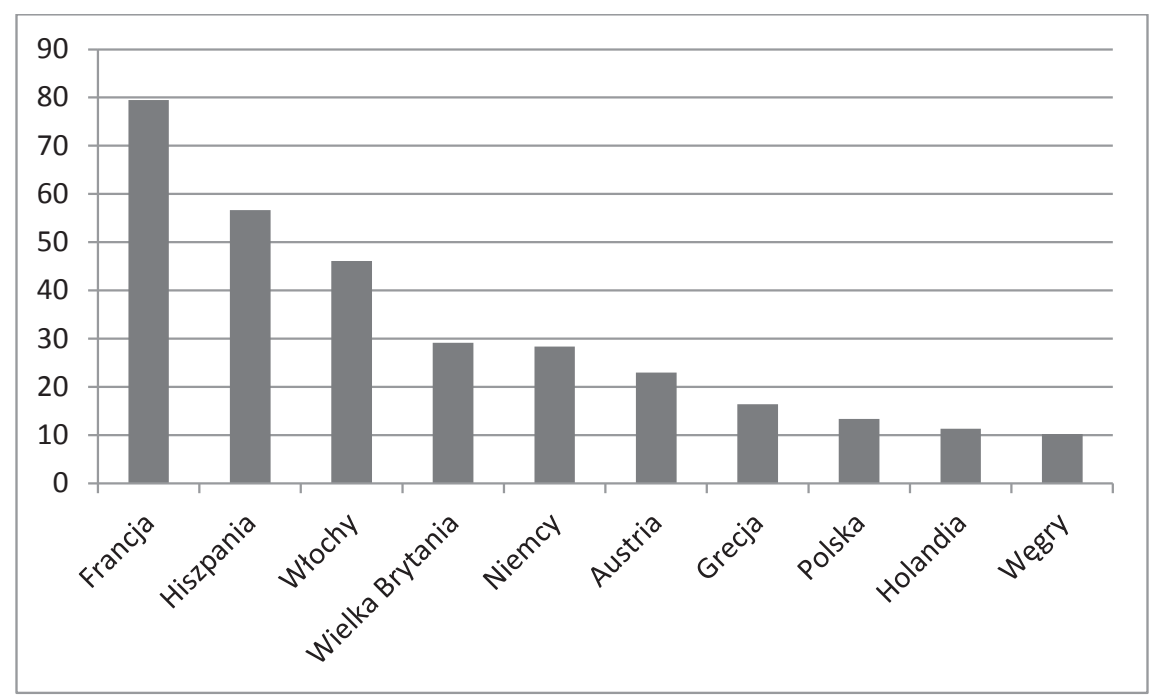

Ryc. 3. Przyjazdy turystów zagranicznych do wybranych krajów UE w 2011 roku (w milionach)

Źródło: opracowanie własne na podstawie UNWTO, World Tourism Barometer 2002-2012

W krajach UE, w których odnotowano największą liczbę przyjazdów turystycznych, czyli we Francji, w Hiszpanii, we Włoszech, a także w Wielkiej Brytanii i Niemczech, natężenie ruchu turystycznego w latach 2001-2011 podlegało wahaniom, niemniej jednak wyraźna była tendencja wzrostowa (ryc. 4). Między 2001 a 2011 rokiem duży wzrost liczby przyjazdów zarejestrowano w Niemczech (o 55\%), a także w Wielkiej Brytanii (o 38\%). W tym samym czasie we Włoszech i w Hiszpanii liczba turystów wzrosła o około 15\%, a we Francji zaledwie o 6,5\%, niemniej jednak kraj ten od wielu lat utrzymuje pozycję pierwszej destynacji przyjazdowej na świecie. We wszystkich tych państwach największą liczbę przyjazdów zarejestrowano pomiędzy 2006 a 2008 rokiem, a także w 2011 roku.

Najwyższą dynamiką zmian w przyjazdach turystów zagranicznych do krajów UE w latach 2001-2011 odznaczały się Dania, Łotwa, Estonia, Bułgaria oraz Słowenia, natomiast najmniejszą - Luksemburg, Węgry i Polska. Ze względu na duże różnice w latach kryzysu ekonomicznego, tj. w okresie 2008-2011, przeanalizowano zmiany w ruchu turystycznym co roku. 


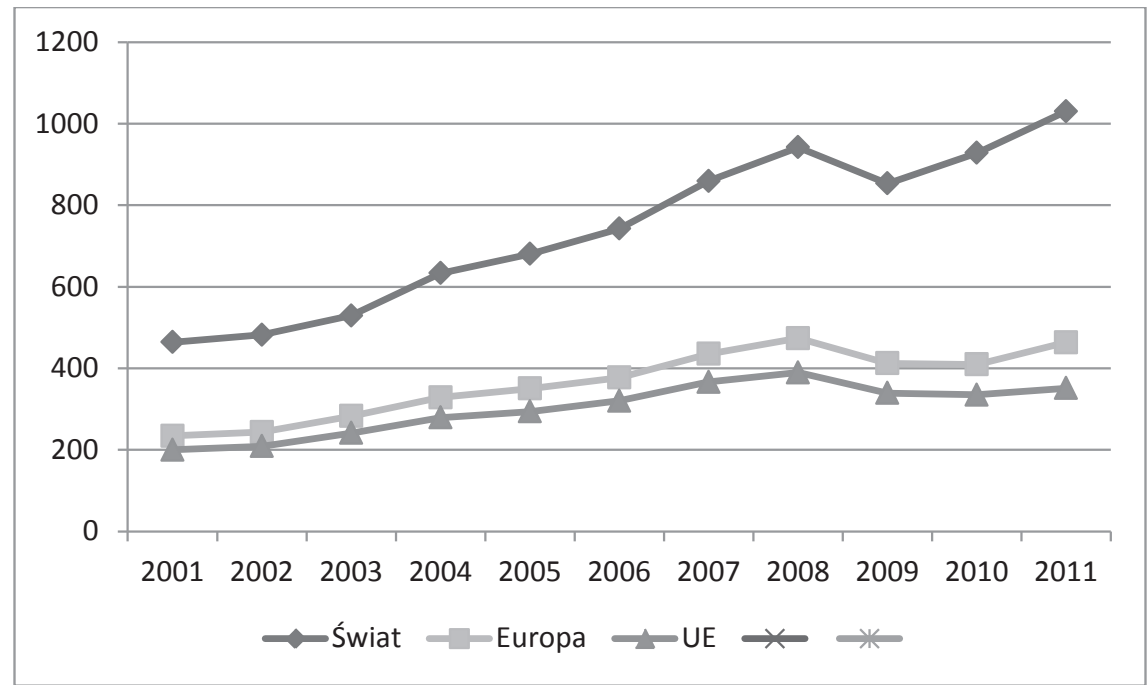

Ryc. 4. Zmiany w przyjazdach turystów zagranicznych do wybranych krajów UE w latach 2001-2011 (w milionach)

Źródło: opracowanie własne na podstawie danych UNWTO, World Tourism Barometer 2002-2012

Pomiędzy 2008 a 2009 rokiem, a więc w okresie, w którym kryzys ekonomiczny niekorzystnie wpłynął na wielkość ruchu turystycznego, największy spadek w przyjazdach turystycznych osiągnęła Słowacja (co mogło być spowodowane wprowadzeniem euro w tym kraju; ryc. 5). Liczba turystów zmniejszyła się tam o 26,5\%. Duży spadek wystąpił też na Lotwie (o 21,4\%) i Litwie (o 16,8\%). W okresie tym wzrost liczby turystów odnotowano jedynie w trzech krajach: w Szwecji (o 2,7\%), we Włoszech (o 1,2\%) i na Węgrzech (o $2,8 \%$ ).

W kolejnym badanym okresie, pomiędzy 2009 a 2010 rokiem, w większości krajów Unii Europejskiej nastąpił wzrost międzynarodowych przyjazdów turystycznych. Największy wzrost wystąpił na Litwie (o 12,4\%), w Estonii (o 11,6\%) i w Niemczech (o 10,9\%). W okresie tym tylko w trzech krajach, a mianowicie w Irlandii (o 9\%), w Luksemburgu (o 6\%) oraz w Rumunii (o 1\%), zmniejszyła się liczba turystów zagranicznych. Pomiędzy 2010 i 2011 rokiem tylko w Luksemburgu zanotowano spadek liczby turystów zagranicznych, a największy wzrost wystąpił na Litwie (o 17,8\%), w Estonii (16,0\%), Finlandii (14,2\%), na Cyprze $(10,1 \%)$ oraz Słowacji $(10,0 \%)$. 


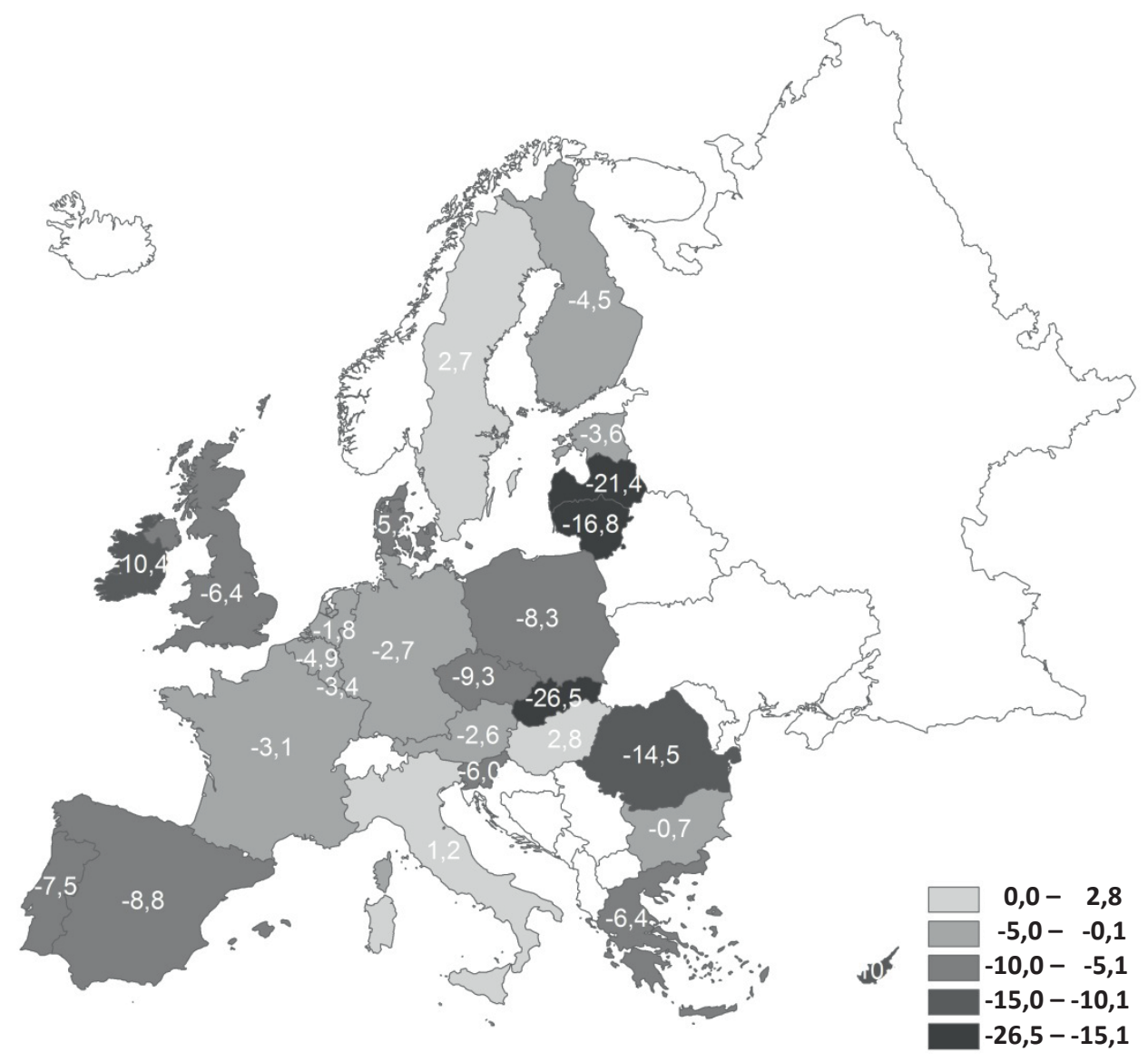

Ryc. 5. Przestrzenne zróżnicowanie zmiany w przyjazdach turystów zagranicznych do krajów UE w latach 2008-2009 (w \%)

Źródło: opracowanie własne na podstawie danych UNWTO, World Tourism Barometer 2002-2012

WPŁYWY Z TURYSTYKI MIĘDZYNARODOWEJ W KRAJACH UNII EUROPEJSKIEJ

Drugim obok liczby przyjazdów turystycznych wskaźnikiem, za pomocą którego charakteryzowany jest ruch turystyczny na świecie, są wpływy z turystyki międzynarodowej. Definiowane są one jako wszelkie przychody danego kraju lub regionu związane z turystyką przyjazdową. Przychody te wylicza się na podstawie wydatków turystycznych, które obejmują wyżywienie, zakwaterowanie, zakupy, rozrywkę, natomiast nie wlicza się do nich kosztów transportu między krajami. 
Podobnie jak w przypadku liczby przyjazdów, wielkość wpływów turystycznych na świecie, w Europie i Unii Europejskiej cały czas rośnie. Zmniejszenie wpływów z turystyki zagranicznej wystąpiło jedynie w 2009 roku (ryc. 6). Na świecie spadły one wówczas o 6,5\%, natomiast w Europie i Unii Europejskiej o 13\%. W 2011 roku wielkość wpływów z turystyki międzynarodowej na świecie oszacowano na 1030 milionów USD, z czego 44\% przypadło na Europę, a 34\% na Unię Europejską. Analiza dochodów z turystyki międzynarodowej w państwach członkowskich Unii Europejskiej dowodzi, że w latach 2001-2011 odnotowano wzrost wpływów aż o ponad $75 \%$.

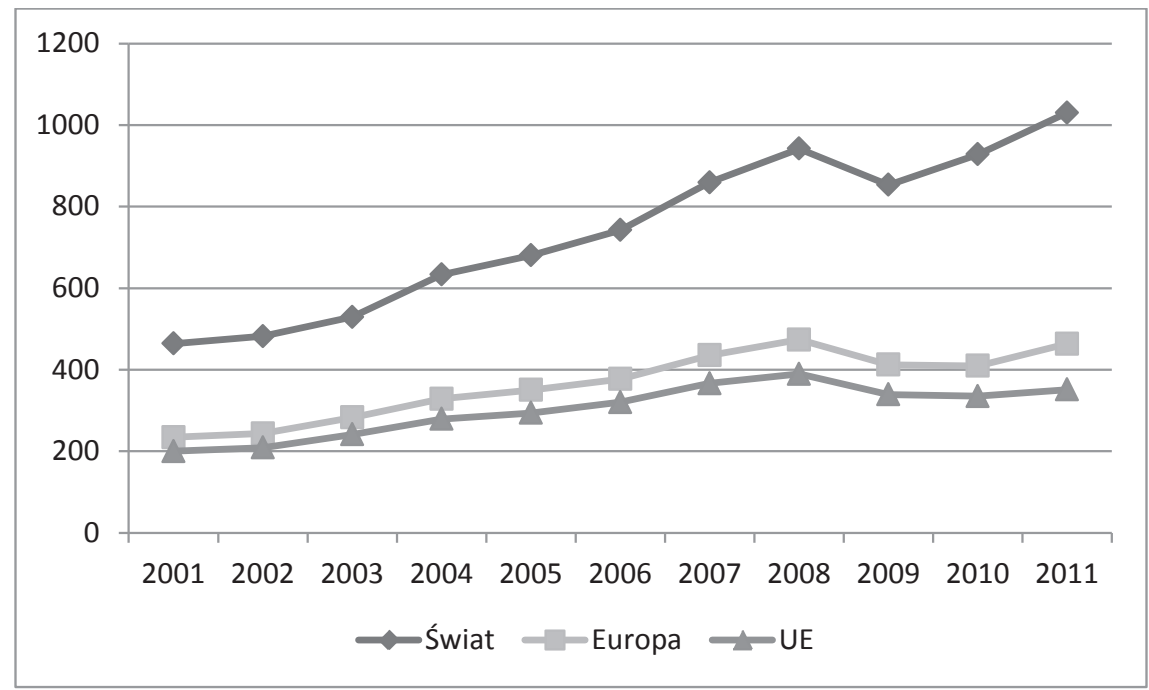

Ryc. 6. Wpływy z turystyki zagranicznej w Europie i na świecie w latach 2001-2011 (w milionach USD)

Źródło: opracowanie własne na podstawie danych UNWTO, World Tourism Barometer 2002-2012, Bulgaria National Statistical Institute, Directorate-general Statistics Belgium, Czech Statistical Office, Danmarks Statistik, Statistics Estonia, INSEE, Direction générale, Ireland Central Statistics Office, Italy Istituto Nazionale di Statistica, Hellenic Statistical Authority, Statistics Lithuania, Hungarian Central Statistical Office, Malta National Statistics Office, Portugal Instituto Nacional de Estatistica, Romania Institutul National de Statistica, Statistisches Bundesamt, Statistical Service of Cyprus, Statistics Sweden, Statistical Office of the Republic of Slovenia, Statistical Office of the Slovak Republic, Statistics Finland, UK Office for National Statistics

Wśród państw Unii Europejskiej głównymi beneficjentami korzyści ekonomicznych z turystyki w 2011 roku były: Hiszpania, Francja, Włochy, Niemcy i Wielka Brytania (ryc. 7). Łącznie w krajach tych wpływy z międzynarodowej turystyki osiągnęły wielkość 232 milionów USD, co stanowi 66\% ogółu wpływów w UE. Wysokość wpływów jest zależna przede wszystkim od stopnia nasilenia przyjazdów turystów. Największe dochody z turystyki zagranicznej osiągają więc kraje, które mają najbardziej rozwiniętą turystykę przyjazdową. Ta zależność dotyczy także regionów Unii Europejskiej, gdzie wpływy z turystyki międzynarodowej również nie rozkładają się równomiernie. W latach od 2001 do 2011 najwyższe wpływy uzyskała Europa Zachodnia oraz Europa Południowo-Śródziemnomorska. 


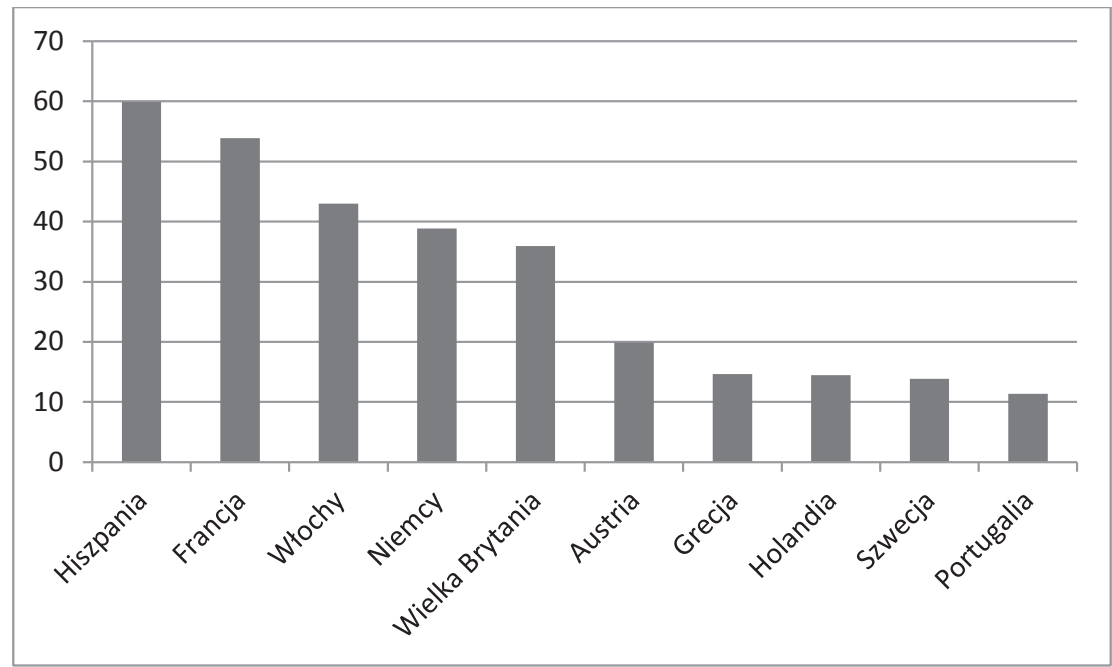

Ryc. 7. Wpływy z turystyki międzynarodowej w wybranych krajach UE w 2011 roku (w milionach USD)

Źródło: opracowanie własne na podstawie UNWTO, World Tourism Barometer 2002-2012

Pomiędzy 2001 a 2011 rokiem w Hiszpanii, we Francji, we Włoszech, w Niemczech i Wielkiej Brytanii wpływy z turystyki międzynarodowej cały czas rosły, z wyjątkiem lat 2009 i 2010, kiedy to wielkość wpływów uległa zmniejszeniu (ryc. 8). Największy spadek wpływów z tytułu obsługi zagranicznego ruchu turystycznego odnotowała wówczas Wielka Brytania (o 22\%), a następnie Francja (o 17,5\%).

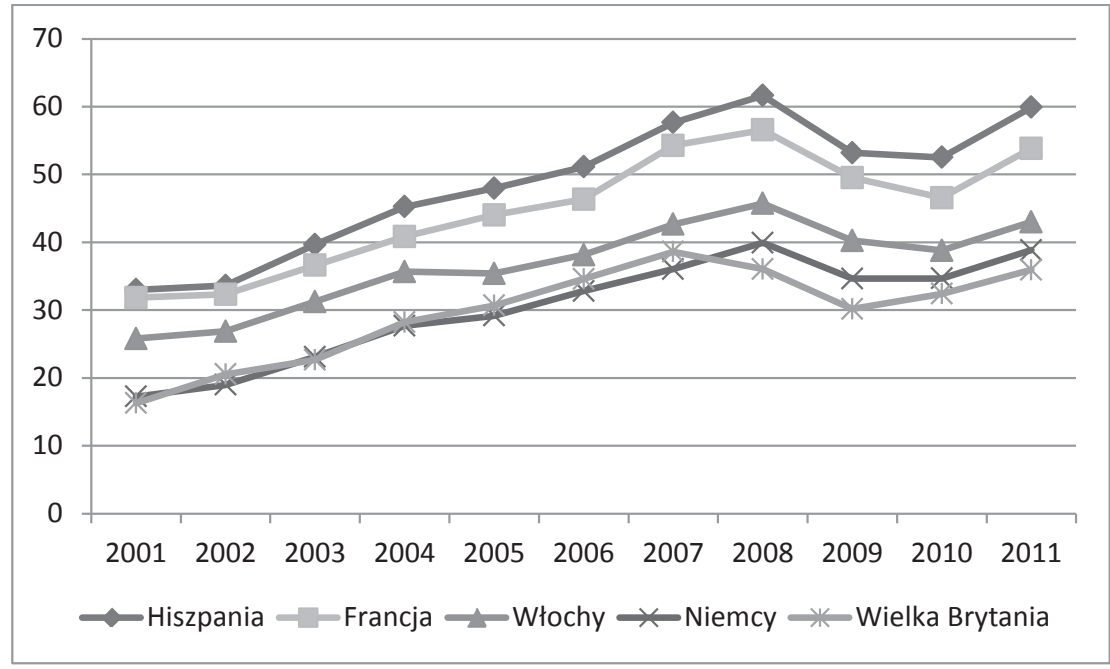

Ryc. 8. Zmiany we wpływach z turystyki międzynarodowej w wybranych krajach UE w latach 2001-2011 (w milionach USD)

Źródło: opracowanie własne na podstawie danych UNWTO, World Tourism Barometer 2002-2012 
Najwyższą dynamiką zmian we wpływach z turystyki międzynarodowej w latach od 2001 do 2011 odznaczają się: Rumunia, Bułgaria, Słowacja, Litwa i Łotwa, natomiast najmniejszą - Dania, Grecja i Węgry. W latach 2008-2009 największe ujemne zmiany we wpływach z turystyki międzynarodowej wystąpiły w Rumunii (spadek wpływów o 38,2\%), Irlandii (22,3\%), na Litwie (24,7\%) i w Polsce (23,4\%). Warto podkreślić, iż w okresie tym w żadnym kraju nie odnotowano wzrostu wielkości wpływów (ryc. 9). W kolejnym okresie, pomiędzy 2009 a 2010 rokiem, w większości krajów Europy Północnej, Europy Środkowo-Wschodniej, a także w Portugalii wystąpił wzrost wpływów z tytułu turystyki międzynarodowej. Najwyższy zarejestrowano wówczas w Szwecji (o 8\%), Wielkiej Brytanii (o 7,5\%), Polsce (o 5,7\%), Portugalii (o 4,5\%), a także w Holandii (o 4,2\%). Z kolei największy spadek wpływów wystąpił w Irlandii (o 16,6\%), w Grecji (o 12,2\%) oraz na Łotwie (o 11,5\%). W okresie 2010-2011 wszystkie kraje UE zanotowały wzrost wpływów z turystyki międzynarodowej, a największy Litwa (o 23,3\%), Szwecja (19,6\%), Finlandia (17,1\%) oraz Rumunia (16,8\%).

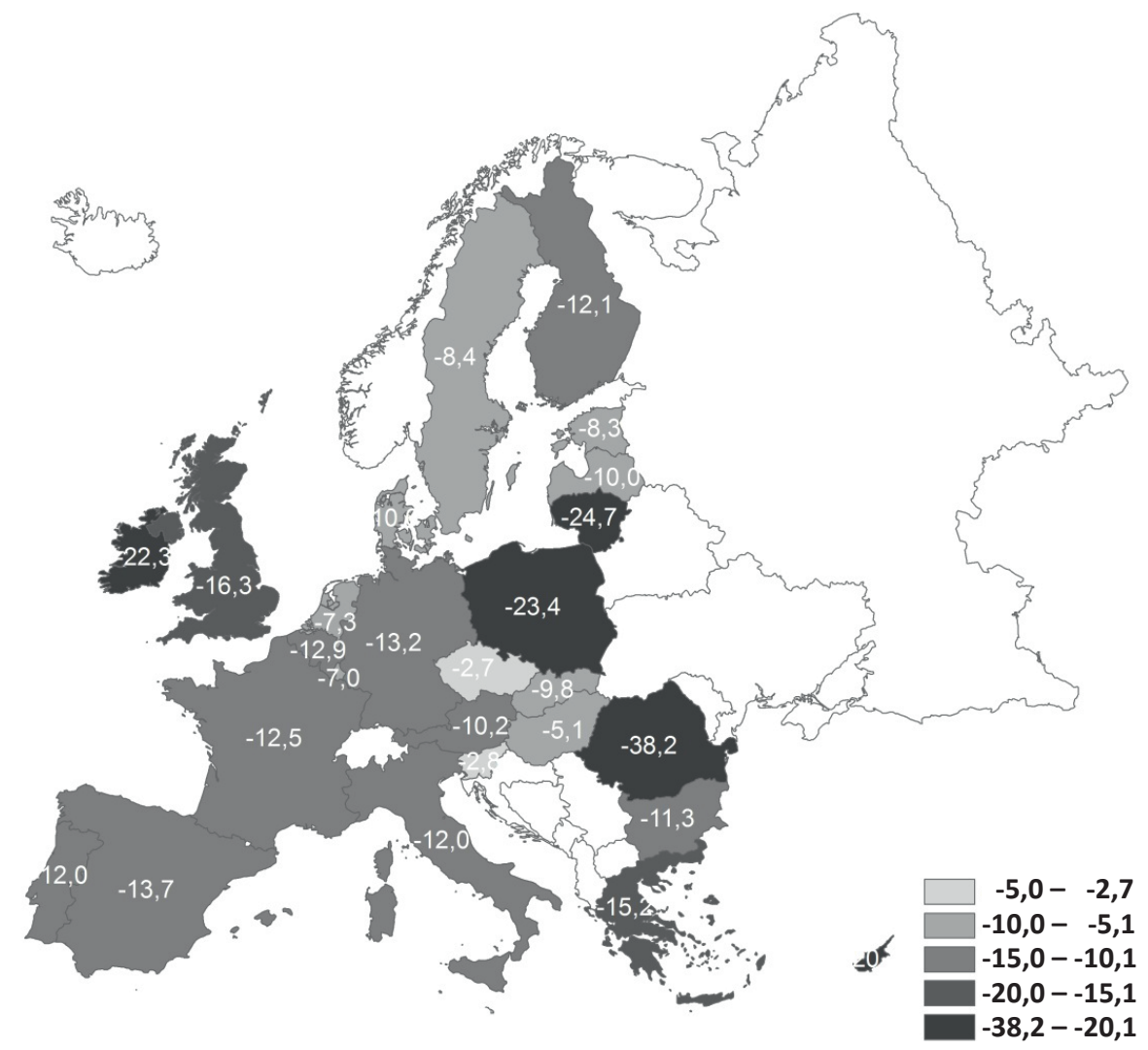

Ryc. 9. Przestrzenne zróżnicowanie zmian we wpływach z turystyki międzynarodowej w okresie 2008-2009 (w \%)

Źródło: opracowanie własne na podstawie danych UNWTO, World Tourism Barometer 2002-2012 
RUCH TURYSTYCZNY W WYBRANYCH KRAJACH UNII EUROPEJSKIEJ

Hiszpania należy do czołówki państw, w których notuje się największą liczbę turystów zagranicznych oraz najwyższe wpływy z tego tytułu. Kraj ten charakteryzuje się wyraźną przewagą zewnętrznego popytu turystycznego. Dochody uzyskiwane z turystyki zagranicznej stanowią około 25-30\% wartości eksportu i charakteryzowały się dużą dynamiką wzrostową (Butowski, 2009).

Najważniejszymi rynkami generującymi ruch przyjazdowy do Hiszpanii są Wielka Brytania, Niemcy i Francja. W ostatnich latach (2008-2011) na terenie Hiszpanii o ponad $50 \%$ wzrosła liczba turystów pochodzących z Rosji, Brazylii i Kanady, natomiast zmalały przyjazdy turystów m.in. z niektórych krajów UE (Niemiec, Wielkiej Brytanii, Portugalii oraz Irlandii).

Wielka Brytania charakteryzuje się przewagą wewnętrznego popytu turystycznego, mimo to uzyskuje wysokie dochody z turystyki zagranicznej i jest najchętniej odwiedzanym krajem UE wśród państw Europy Północnej. W latach 2008-2011 najwięcej turystów przybyło tam z Francji (ok. 12-13\%), Irlandii (ok. 9-10\%), USA (10\%), Niemiec (ok. 10\%), Hiszpanii (ok. 6-8\%) i Holandii (6\%). W latach od 2008 do 2011 na terenie Wielkiej Brytanii o ponad 50\% wzrosła liczba turystów pochodzących z Maroka, Brazylii, Rumunii, a o 54\% zmniejszyły się przyjazdy turystyczne $\mathrm{z}$ terytorium Słowacji.

Francja należy do krajów najczęściej odwiedzanych przez turystów z całego świata. Dochody uzyskiwane z turystyki międzynarodowej mają duże znaczenie dla jej gospodarki. Najliczniejszą grupę turystów zagranicznych we Francji stanowią Brytyjczycy (ok. 15-16\%), Niemcy (ok. 13-15\%), Belgowie (ok. 10-14\%), Włosi (ok. 9-10\%) i Holendrzy (ok. 6-10\%). Warto dodać, że pomiędzy 2008 a 2011 rokiem wystąpił we Francji znaczny wzrost liczby turystów pochodzących z innych kontynentów. Ponad dwukrotnie wzrosła liczba turystów z Afryki, a o 41\% z Azji i Oceanii.

W 2011 roku Włochy odwiedziło ponad 46 milionów turystów. W latach 2008-2011 najważniejszymi rynkami generującymi ruch przyjazdowy do Włoch były Szwajcaria (ok. 17-18\%), Niemcy (ok. 15-16\%), Francja (ok. 13-14\%) i Austria (ok. 8-10\%). W tym samym okresie o $81 \%$ zwiększyła się liczba turystów pochodzących z Rosji, a o $40 \%$ zmniejszyły się przyjazdy turystów będących obywatelami Węgier, ponadto Norwegii, Wielkiej Brytanii, Grecji oraz Irlandii.

Państwa Unii Europejskiej najczęściej odwiedzane są przez turystów z krajów sąsiednich bądź z krajów położonych niewiele dalej. Wynika to głównie ze względów ekonomicznych, a także z pokrewieństwa kultury. Przyczyna tkwi również w maksymalnej liberalizacji ruchu granicznego w UE (umowa z Schengen) (Kruczek, 2008). 
ZMIANY W STRUKTURZE WIEKU TURYSTÓW ZAGRANICZNYCH

Pomimo kryzysu finansowego, w okresie 2006-2011 w UE wzrosła liczba turystów zagranicznych w wieku 65 lat i więcej (o 12,7\%), podczas gdy spadek zanotowano w liczbie turystów w młodszych grupach wiekowych (ryc. 10). Po części wzrost liczby turystów w starszym wieku związany jest z przemianami demograficznymi zachodzącymi w Europie, polegającymi na starzeniu się ludności (wzrost liczby osób w wieku $65+$ o 6,4\%, a osób w wieku 45-64 o 7,9\%). W efekcie udział turystów w wieku 65 lat i więcej uczestniczących w międzynarodowym ruchu przyjazdowym wzrósł z 10,9\% do 14,4\% w latach 2006-2011 według danych Eurostatu. Turyści w wieku emerytalnym mają siłę nabywczą i dysponują wolnym czasem, stanowiąc znaczący potencjał rynkowy dla usług turystycznych. Wymaga to jednak dostosowania się gospodarki i sektora turystycznego do zaspokajania ich potrzeb, albowiem inna jest struktura konsumpcji i wydatków osób starszych, które preferują także inne formy spędzania czasu wolnego niż osoby młodsze. W 2011 roku turyści w wieku 65 lat i więcej zrealizowali o 44\% więcej wyjazdów zagranicznych niż 5 lat wcześniej. Ich wydatki wzrosły o 48,7\%, podczas gdy w grupie 25-44 lat zmalały o 24\%. W 2011 roku wydatki turystów zagranicznych w wieku $65+$ stanowiły $19 \%$ ogółu wydatków wobec $12 \%$ w 2006 roku. Największym odsetkiem turystów w wieku emerytalnym, uczestniczących

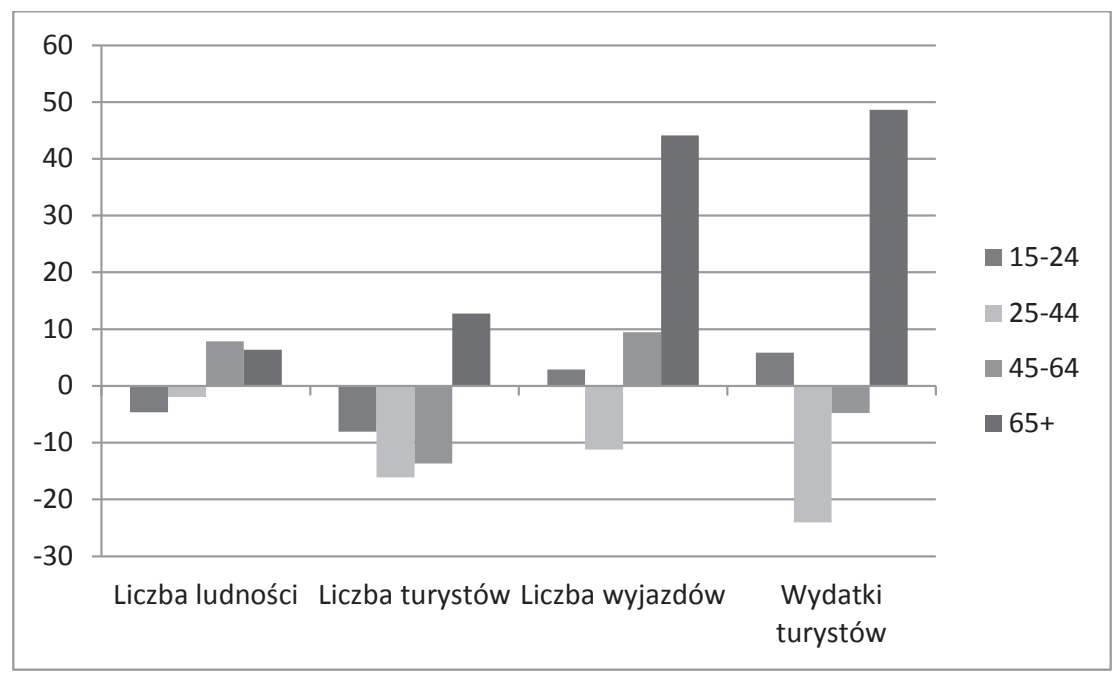

Ryc. 10. Zmiany w liczbie ludności ogółem, liczbie turystów zagranicznych, liczbie wyjazdów zagranicznych oraz wydatków turystów zagranicznych według wieku w Unii Europejskiej w latach 2006-2011 (w \%)*

Źródło: opracowanie własne na podstawie danych EUROSTAT

* Dane obejmują wyjazdy trwające minimum 4 doby; dla liczby turystów zagranicznych dane bez Bułgarii, Estonii, Malty, Irlandii, Rumunii, Litwy i Słowacji, dane dla liczby wyjazdów zagranicznych bez Bułgarii, Danii, Estonii, Irlandii, Malty i Austrii oraz dane dla wydatków turystów bez Belgii, Bułgarii, Czech, Danii, Estonii, Irlandii, Litwy, Malty, Austrii, Rumunii, Finlandii i Włoch. 
w międzynarodowym ruchu przyjazdowym w 2011 roku, charakteryzowały się kraje zamożniejsze, jak np.: Dania (24,5\%), Szwecja (22,6\%), Niemcy $(17,6 \%)$ oraz Holandia $(17,2 \%$; ryc. 11). Dużą rolę odgrywa także turystyka rezydencjonalna osób starszych z Europy Północnej i Zachodniej do regionu śródziemnomorskiego, gdzie obszary o atrakcyjnych walorach klimatycznych, krajobrazowych i kulturowych przyciągają zamożniejszych emerytów (King, Patterson, 1998; Mantecón, 2010; Rodríguez, Fernández-Mayoralas, Rojo, 1998; Sedgley, Pritchard, Morgan, 2011; Warnes, Patterson, 1998; Williams, Patterson, 1998).

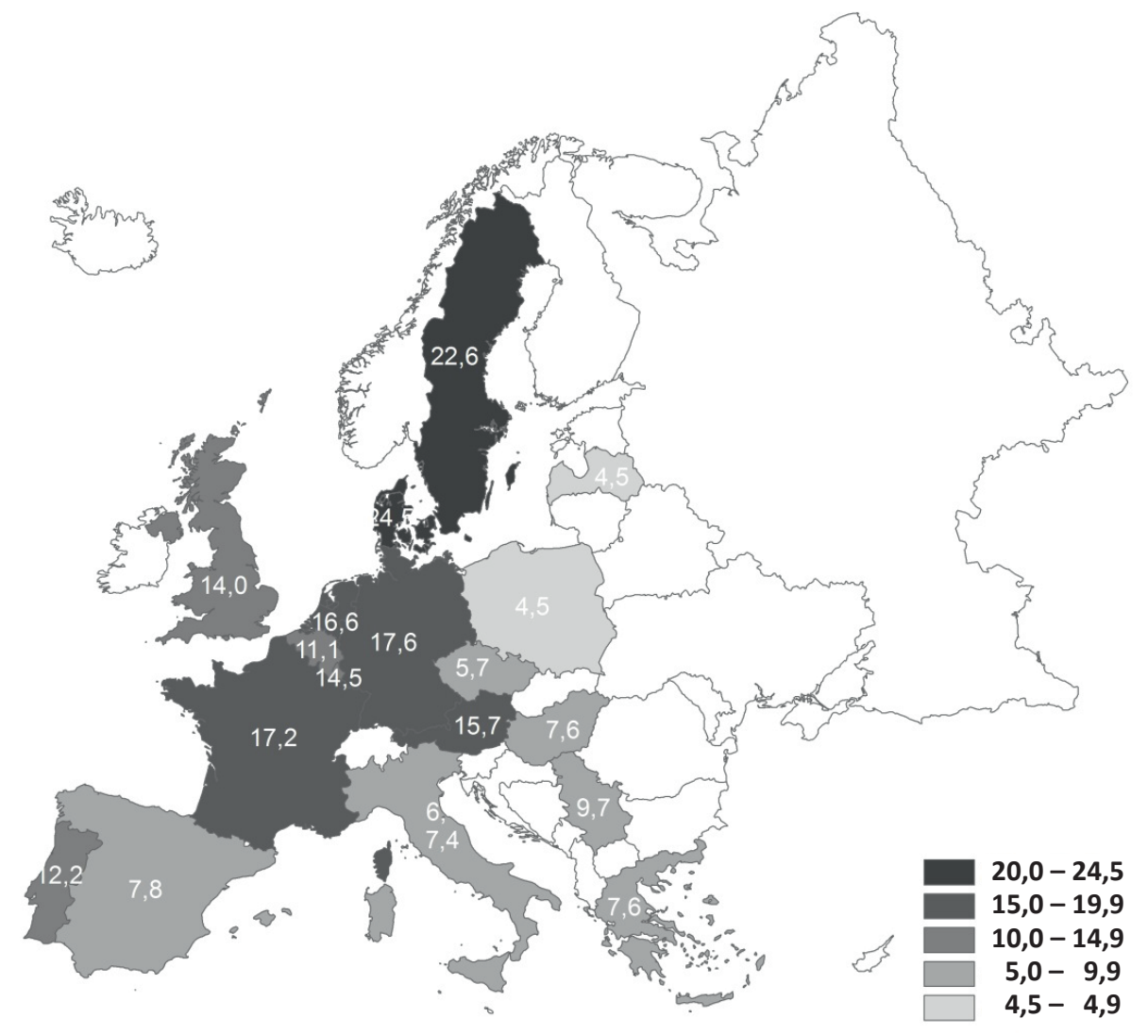

Ryc. 11. Udziały turystów w wieku 65 lat i więcej, uczestniczących w międzynarodowym ruchu przyjazdowym w 2011 roku (w \% ogółu turystów zagranicznych)

Źródło: opracowanie własne na podstawie danych EUROSTAT

Turystyka w Unii Europejskiej, będąc ważnym sektorem gospodarki i wywierając znaczący wpływ na wzrost gospodarczy i zatrudnienie w Europie, stała się obiektem zainteresowania Komisji Europejskiej, która ogłosiła nowe ramy polityczne dla europejskiego sektora turystycznego, zwłaszcza w warunkach kryzysu (Komisja Europejska, 2010). Odczuwalny od 2008 roku kryzys gospodarczy i finansowy spowodował zmniejszenie popytu na usługi 
turystyczne. W 2009 roku obroty w europejskiej branży turystycznej spadły więc o około 5,6\% (UNWTO World Tourism Barometer, 2010). Turyści europejscy decydowali się na krótsze i bliższe wyjazdy oraz ograniczali wydatki w miejscach pobytu. Dodatkowo branża turystyczna znacząco odczuła zamknięcie przestrzeni powietrznej w kwietniu i maju 2010 roku, spowodowane obecnością chmur pyłu wulkanicznego znad Islandii.

Według Komisji Europejskiej (2010: 8-9), polityka turystyczna Unii Europejskiej we współczesnej sytuacji społeczno-ekonomicznej winna koncentrować się w czterech obszarach działania:

1) stymulowanie konkurencyjności sektora turystycznego w Europie;

2) wspieranie rozwoju zrównoważonej i odpowiedzialnej turystyki wysokiej jakości;

3) konsolidacja wizerunku i widoczności Europy jako zbioru kierunków turystycznych wysokiej jakości i opartych na zasadach zrównoważonego rozwoju;

4) pełne wykorzystanie potencjału różnych obszarów polityki i instrumentów finansowych UE na rzecz rozwoju turystyki.

Europa, aby utrzymać pozycję najpopularniejszej destynacji turystycznej na świecie, musi sprostać współczesnym wyzwaniom polityki turystycznej, które obejmują m.in.:

- tworzenie korzystnych warunków dla rozwoju turystyki w Europie, z uwzględnieniem ochrony dziedzictwa przyrodniczego i kulturowego;

- wzmocnienie odporności sektora turystycznego na skutki zmian klimatycznych;

- zwiększenie elastyczności wskutek zmian strukturalnych (np. przemian demograficznych prowadzących do starzenia się społeczeństwa).

\section{Podsumowanie}

W latach 2008-2009 światowy kryzys gospodarczy wpłynął na załamanie rynku turystyki międzynarodowej zarówno w zakresie liczby turystów zagranicznych, jak i wpływów z turystyki. Niemniej jednak w 2010 roku nastąpił powrót do trendu wzrostowego, który został utrzymany także w 2011 roku. Wśród krajów najchętniej odwiedzanych przez turystów zagranicznych nadal dominują w strukturze turystów według kraju pochodzenia te same państwa, natomiast w ujęciu dynamicznym nastąpił wzrost przyjazdów turystów spoza Unii Europejskiej, a niektóre kraje unijne odnotowały spadek przyjazdów. Wraz ze zmianami demograficznymi nastąpił w ostatnich latach wzrost znaczenia przyjazdów i wydatków turystów zagranicznych w starszym wieku (udział oraz wydatki), a największym udziałem turystów w wieku 65 lat i więcej w międzynarodowym ruchu przyjazdowym charakteryzują się kraje Europy Zachodniej i Północnej. 


\section{Literatura}

Butowski, L. (2009). Turystyka w polityce spójności gospodarczej i społecznej Unii Europejskiej, Warszawa: Wydawnictwo Difin.

Dziedzic, T., Łopaciński, K., Saja, A., Szegidewicz, J. (2009). Wpływ światowego kryzysu gospodarczego na stan i perspektywy rozwoju sektora turystyki w Polsce. Warszawa: Departament turystyki Ministerstwa Sportu i Turystyki.

EUROSTAT (2012a). Tourism in the EU 27. Newsrelease, 99/2012 - 28 June 2012, http://ec.europa. eu/eurostat.

EUROSTAT (2012b). Tourism in Europe: Results for 2011. Statistics in Focus, 28/2012, http://ec.europa.eu/eurostat.

Eurostat Regional Yearbook (2012). EUROSTAT, European Commission.

Gierańczyk, W., Rachwał T. (2012). Structural Changes in the Industry of Poland Against the Background of Eastern European Union States. Quaestiones Geographicae, 31(2), 83-93.

Gotowt-Jeziorska, A., Łopaciński, K. (red.) (2011). Turystyka w Polsce w okresie kryzysu. Warszawa: Polskie Stowarzyszenie Turystyki.

King, R., Patterson, G. (1998). Diverse Paths: the Elderly British in Tuscany. International Journal of Population Geography, 4, 157-182.

Komisja Europejska (2010). Europa - najpopularniejszy kierunek turystyczny na świecie - nowe ramy polityczne dla europejskiego sektora turystycznego. Komunikat Komisji do Parlamentu Europejskiego, Rady, Europejskiego Komitetu Ekonomiczno-Społecznego i Komitetu Regionów, Bruksela, KOM (2010), 352.

Kruczek, Z. (2008). Europa. Geografia turystyczna, Kraków: Wydawnictwo Proksenia.

Mantecón, A. (2010). Tourist Modernisation and Social Legitimation in Spain. International Journal of Tourism Research, 12, 617-626.

Mika, M., Faracik, R. (2008). Międzynarodowy ruch turystyczny. W: W. Kurek (red.). Turystyka, Warszawa: PWN, 66-120.

Nosek, A., Pietrzak, A. (2009). Efekt domina czyli międzynarodowa transmisja kryzysów - na przykładzie wspótczesnego kryzysu finansowego. W: W. Michalczyk (red.). Wybrane problemy gospodarki światowej pierwszej dekady nowego wieku, Wrocław: Uniwersytet Ekonomiczny we Wrocławiu, 82-92.

Pawlicz, A. (2011). Turystyka międzynarodowa. W: P. Panasiuk (red.). Ekonomika turystyki, Warszawa: PWN, 182-199.

Rodríguez, V., Fernández-Mayoralas, G., Rojo, F. (1998). European Retirees on the Costa del Sol: a Cross-national Comparison. International Journal of Population Geography, 4, 183-200.

Sedgley, D., Pritchard, A., Morgan, N. (2011). Tourism and Ageing. A Transformative Research Agenda. Annals of Tourism Research, 38 (2), 422-436.

UNWTO World Tourism Barometer (2010), 8(1), www.unwto.org/facts/eng/pdf/barometer/UNWTO Barom10_1_en.pdf.

Warnes, A.M., Patterson, G. (1998). British Retirees in Malta: Components of the Cross-national Relationship. International Journal of Population Geography, 4, 113-133.

Williams, A.M., Patterson, G. (1998), An Empire Lost but a Province Gained': a Cohort Analysis of British International Retirement in the Algarve. International Journal of Population Geography, $4,135-155$.

Zdon-Korzeniowska, M., Rachwał, T. (2011). Turystyka w warunkach światowego kryzysu. W: Z. Zioło, T. Rachwał (red.). Przemiany struktur lokalnych i regionalnych sektora usług w latach kryzysu gospodarczego. Prace Komisji Geografii Przemystu Polskiego Towarzystwa Geograficznego, 18, 116-128. 
Sławomir Kurek, dr hab., prof. UP, Uniwersytet Pedagogiczny w Krakowie.

Profesor Uniwersytetu Pedagogicznego w Instytucie Geografii, w Zakładzie Geografii Społeczno-Ekonomicznej. Zainteresowania badawcze: przemiany demograficzne w Polsce i na świecie, zmiany zachowań prokreacyjnych, proces starzenia się ludności, turystyka międzynarodowa, edukacja przedsiębiorczości. Dorobek zawarty jest w 96 pracach, z czego 25 zostało opublikowanych po otwarciu przewodu habilitacyjnego. Dorobek obejmuje dwie monografie, 17 publikacji w wydawnictwach zagranicznych (w tym trzy z listy filadelfijskiej: „Journal of Curriculum Studies”, „Geografiska Annaler” oraz „Population, Place and Space”), 6 artykułów oryginalnych w języku angielskim w polskich czasopismach naukowych (w „Bulletin of Geography”). Ponadto jest autorem podręcznika do geografii dla szkół średnich (poziom podstawowy do nowej podstawy programowej).

Sławomir Kurek, Associate professor at Pedagogical University of Cracow, Institute of Geography, Department of Socio-economic Geography. Research interests: demographic changes in Poland and the world, changes in the reproductive behaviour, population ageing, international tourism, entrepreneurship education. His scientific output comprises 96 publications, of which 25 were published after habilitation. The list of publications includes 2 monographic books, 17 papers published abroad (including three articles recorded at Journal Citation Reports: Journal of Curriculum Studies, Geografiska Annaler and Population, Place and Space), 6 original papers in English in Polish Scientific journals (Bulletin of Geography). In addition to that he is an author of a geography handbook for students of upper level secondary school (basic level for a new core curriculum).

Paulina Waclawik, mgr, doktorant, Uniwersytet Pedagogiczny w Krakowie.

Doktorantka w Instytucie Geografii Uniwersytetu Pedagogicznego w Krakowie. Absolwentka Uniwersytetu Jagiellońskiego w Krakowie. Zainteresowania badawcze: rozwój regionalny, turystyka kulturowa, regionalne produkty turystyczne, antropologia kultury, antropologia przestrzeni miejskich i etnomuzykologia.

Paulina Waclawik, PhD Student in the Institute of Geography at Pedagogical University of Cracow. She graduated from Jagiellonian University in Cracow. Her academic interests include regional development, cultural tourism, regional touristic products, anthropology of culture, anthropology of urban space and ethnomusicology.

adres/address: Uniwersytet Pedagogiczny w Krakowie

Instytut Geografii

ul. Podchorążych 2, 30-084 Kraków, Polska

e-mail: sgkurek@up.krakow.pl (Sławomir Kurek)

p.waclawik@wp.pl (Paulina Wacławik) 